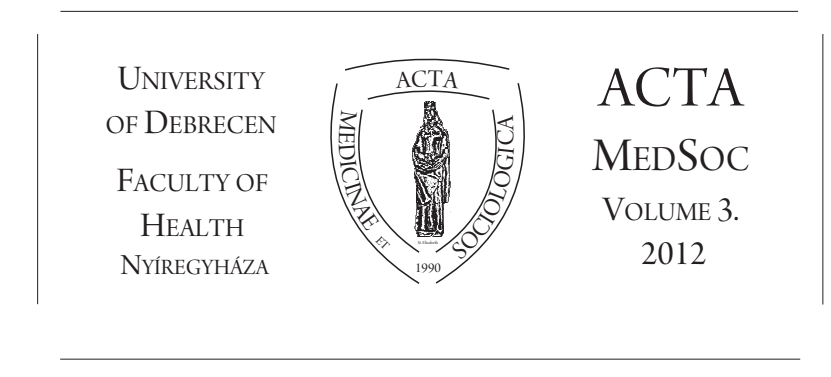

\title{
Szociális dimenziók a fogyatékossággal élố tanulók oktatása-nevelése terén
}

\author{
Belényi Emese \\ Partiumi Keresztény Egyetem, Nagyvárad Bölcsészettudományi Kar, \\ Társadalomtudományi Tanszék
}

\begin{abstract}
Socio-pedagogical dimensions in the education of learners living with disabilities.

In recent years the concepts of educational inclusion and inclusive education, which are linked to the new human rights-centred approach on disability, gained a fully legitimate place as key terms both in guiding action oriented social research and in shaping social and educational policies in this field. Yet, the pace of change towards the new outlook and new policies concerning the educational opportunities and services available for disabled learners are hindered by a series of obstacles. These are generated, on the one hand, by still unresolved conceptual and methodological problems and on the other hand by the persistence of outdated institutional structures and mentality. After a presentation of the theoretical and historical background of occurring changes, the following paper will discuss possible causes which have led to the present situation, and will also outline potential solutions and ways for improvement.
\end{abstract}

Keywords: educational inclusion, equal opportunities, learners with special needs, disability, inclusive education

DOI: $10.19055 / \mathrm{ams} .2012 .3 / 4-5 / 4$ 


\section{Egy paradigmaváltás és következményei}

A társadalomtudományok - ezen belül a pedagógia, a szociológia és határtudományaik, köztük kiemelt helyen a szociálpedagógia - szerepe, funkciói és vizsgálódási módja terén az utóbbi évtizedekben jelentôs változásnak lehettünk tanúi. A megismerô funkciót abszolutizáló koncepciók helyett a társadalmi változás elôsegítését felvállaló felfogások kerülnek mindinkább előtérbe. Egyrészt a napjaink értékválságára adott társadalomtudományi válaszként, másrészt pedig az emberi jogok, az esélyegyenlőség problematikájának a politikai ideológiában és gyakorlatban való felértékelődésének szociológiai lecsapódásaként mindinkább elterjedtebbé és egyre fontosabbá válnak az emberjogi megalapozottságú, normatív jellegú megközelítésmódok, amelyeket a hátrányos helyzetú társadalmi csoportok sorsának javítása iránti elkötelezettség jellemez. (Blau, 2010)

Napjaink szociológiai elméleteinek fontos témái többek között a globális és lokális társadalom kapcsolata, az identitás szerepének erôsödése és sajátos alakulása a globális hatalmi-financiális-technológiai hálózatokból kiszorítottak körében (Castells 2004), a tiltakozó mozgalmak társadalmi változást elôidézô szerepe (Bourdieu 1969), valamint a társadalmi változás lehetséges modelljei (Coleman 1964, Bohrnstedt 1969). A hagyományos-klasszikus szemléletmóddal szemben, amely programatikusan értéksemlegességre törekszik, a fennálló társadalmi struktúrákat adottságként felfogó, implicit módon a status quo-t támogató, a társadalmi-politikai gyakorlathoz a tudós távolságtartásával viszonyuló kutatói attitűdöket favorizálja, mindinkább érvényesül az a felfogás, amely a szociológia kognitív funkcióját a társadalmi lét optimalizálásának szolgálatába állítja.

E kontextusban a szociálpedagógián belül is fokozódik a rokon társadalomtudományoknak a szakterület szempontjából fontosnak ítélt eredményei iránti igénye. A segítségre szorulók társadalmi helyzetét befolyásoló okok vizsgálata természetszerûen összekapcsolódik a hatékony beavatkozás módozatainak feltárására irányuló olyszerü törekvésekkel, amelyek a politikai szerepvállalás szükségszerúségét tüzik napirendre. „A célkitúzés az, hogy a szociálpedagógia ne csak vészhelyzetekben avatkozzon be, vagyis amikor már lényegében késő [... ] hanem, hogy munkájával pont az ilyen helyzetek kialakulását akadályozza meg, illetve csökkentse" (Kozma - Tomász 2000, p 12).

A fentiekben körvonalazott paradigmaváltás összefüggésében értelmezhetô a fogyatékossággal kapcsolatos szemléletmód terén elindult - de még korántsem befejezett - változás is, amelynek lényege: áttérés a fogyatékosság orvosi értelmezési modelljérôl a fogyatékosság társadalmi modelljére. Ez az átmenet egyrészt szükségszerú következménye a társadalomtudományi, pedagógiai és közpolitikai megközelítések tekintetében bekövetkezett szemléletváltásnak, ugyanakkor maga is további, hasonló irányú változásokat indukál mind a fogyatékos személyeket érintő közpolitikák, mind pedig a velük kapcsolatos speciális nevelési gyakorlatok terén.

Az orvosi modell a sérültséget elsôsorban az egyén biológiai-egészségbeli hiányaként fogja fel, csökkentértékűségként, amelyet különféle gyógymódok, technikai se- 
gítő eszközök igénybevételével tart részlegesen kompenzálhatónak. Mindenekelőtt a fogyatékos egyéntôl vár alkalmazkodást a meglévő társadalmi feltételekhez, s ehhez kínál kompenzáló jellegú segítséget. Főként az egészség-betegség, csökkent munkaképesség, rehabilitáció, reintegráció fogalmaiban gondolkodik. E modell lényegét jól kifejezi az Egészségügyi Világszervezet 1980-as értelmezése, miszerint „betegségek, sérülések, fejlődési rendellenességek, valamint környezeti tényezôk, társadalmi elvárások és attitűdök eredményeként károsodások, fogyatékosságok és rokkantság" alakulhat ki, egy irányban, folyamatosan súlyosbodó helyzetbe hozva az érintett embert. Ezt a folyamatot fogyatékossági folyamatként nevezték el. (Kullmann és Kun 2004, p. 72)

Az orvosi modell nem veszi figyelembe azt a tényt, hogy a testi vagy mentális károsodásból közvetlenül nem fakad társadalmi hátrány. A társadalmi hátrány abból származik, ahogyan viszonyul a sérült emberhez annak társadalmi környezete, ahogyan ôt kezeli. A mozgás korlátozottsága például valóban egy ember képességeivel kapcsolatos helyzet. Az a tényállás azonban, hogy a mozgáskorlátozott emberek számára nem állnak rendelkezésre kisegítô eszközök (például rámpák), amelyek lehetôvé tennék számukra a középületekbe vagy szolgáltató intézményekbe való bejutást, az már társadalmi környezettel kapcsolatos tényezô. A hallásssérültség is az egyént érintő tény. Ha azonban a hallássérült egyénnek jelnyelvi vagy feliratos fordítás hiánya miatt nincs lehetősége hozzáférni például a televíziós adásokhoz, az már a társadalmi környezettel kapcsolatos tényállás. Ha egy elégtelen foglalkoztatáspolitika és a munkaadók hozzállása, a társadalmi attitűdök következtében aránytalanul kevés sérült embert találunk a munkahelyeken annak ellenére, hogy számos munkakört el tudnának látni, az már a társadalmi környezettel kapcsolatos tény. (Kullman és Kun 2004, p. 81)

Válaszképpen az orvosi modell hiányosságaira, a sérült személyek és szervezeteik kidolgozták az önálló, önrendelkezó élet társadalmi modelljét, és mintegy szembeállították azt az orvosi modellel. Ebben - az emberi jogokra alapozva - abból indulnak ki, hogy az emberek nagyon sok szempontból eltérnek egymástól, és nemcsak az egészségi állapot, vagy bizonyos testi sajátosságokkal összefüggó képességek megléte, illetve hiánya adja ezeket a különbségeket. Nem az emberek különbözôségének orvosi osztályozásával kell tehát foglalkozunk, hanem olyan társadalmi környezet kialakításával, hogy abban mindenki képességeinek megfelelôen, azokat kihasználva, a képességéhez szabott szolgáltatásokat igénybe véve egyenló esélyekkel tudjon tevékenykedni és részt venni. (Matinvesi 1999; Pacifici 1999).

A társadalmi modell a fogyatékosságot elsôsorban a fogyatékos személy sajátos szükségletei és a társadalom szükséglet-kielégítő szolgáltatásai közötti meg nem felelésként definiálja. (Oliver 1996 In: Davies 2008). Mindenekelőtt a társadalomtól vár alkalmazkodást a sérült személy sajátos szükségleteihez, az egyén teljes mértékû társadalmi érvényesülése érdekében. Kulcsfogalmai: inklúzió, integráció, adaptáció, non-diszkrimináció, egyenlő esélyek, sajátos szükségletek, sajátos nevelési igények. A fogyatékosságról szóló redukcionista értelmezéseket olyan társadalmi konstruktumokként határozza meg, amelyeket a társadalom struktúrája, 
magatartás- és viszonyrendszere termel ki, és a fennálló hatalmi viszonyok konzerválják. E látásmód szerint a fogyatékossággal kapcsolatos leegyszerúsített, sztereotipikus gondolkodásmód ellensúlyozása édekében olyan „ellen-narratívákra” van szükség, amelyek a negatív társadalmi percepciókkal, attitűdökkel felvállalt küzdelem személyes élettapasztalatán alapulnak. (Ferri, 2008)

\section{Integráció (és/vagy?) inklúzió}

Az integrációs törekvések kibontakozása az 1960-as években különbüzó motivációkkal indult be. A skandináv országokban a kiindulópont az ún. normalizációs elv volt, miszerint a társadalom minden tagjának, a fogyatékos embereknek is joguk van „normális” azaz bizonyos általánosnak elfogadott standardoknak megfeleló életet élni, a fogyatékos embereknek pedig emellett joguk van speciális igényeik kielégítéséhez is. „Ez az elv már az 50-es években hangsúlyozza, hogy a fogyatékos emberek számára olyan életfeltételeket kell teremteni, amelyek a legnagyobb mértékben közelítenek a normális életfeltételekhez" (Lányiné 1993, p. 12). A normalizációs elv következményeként a hetvenes-nyolcvanas években például Dániában már mind nagyobb figyelmet szenteltek azoknak a tanulóknak, akiknek tanulási nehézségeik voltak, s mintegy 12-13\%-ukat részesítették a többségi iskola keretei között speciális megsegítésben. Az arány megváltozott, a korábban speciális iskolákba járók száma jelentôsen csökkent. (Csányi - Perlusz 2001, p. 316)

Az Amerikai Egyesült Államokban a pozitív irányú változások mozgatóerejét a polgárjogi mozgalmak képezték, amelyek a fogyatékos emberek jogaiért és az elkülönítettség megszüntetéséért szálltak síkra. Az 1975-ben megjelent s a mai napig gyakran hivatkozott oktatási törvény kimondja a legkevésbé korlátozó környezet biztosításának szükségességét minden fogyatékos számára, s ezzel egyidejúleg azt, hogy a legkedvezőbb iskolai környezetet a többségi iskolához viszonyított lehető legközelebbi elhelyezés jelenti. A tanulók zöménél a fenti követelmény teljesülését az integráció révén látják biztosítva, de nem zárják ki a szegregált elhelyezés lehetôségét sem, túlnyomórészt a többségi iskolákban múködő speciális osztályok keretében. (Csányi-Perlusz 2001, p. 317)

Olaszországban hasonló következményekkel járó szerepet töltöttek be az ún. antipszichiátriai mozgalmak, amelyek egy adott ponton minden állami fenntartású gyógypedagógiai intézmény felszámolásához jutottak el, s eközben kialakították a többségi iskolák integrációs feltételrendszerét. Amikor egy törvény megszüntette a tanköteles korú fogyatékos gyermekek speciális osztályainak az indítását, 1977tôl kezdődôen az iskoláskorú gyermekek 99,9 százaléka többségi iskolákba járt. Az olasz törvényhozás és a bíróság többször megerősítette az integrációs elvet, mint a speciális szükségletú gyerekekkel való bánásmód nemzeti modelljét. A törvények következetesek, az osztálylétszám maximalizálva védett, hagyományos osztálytanítókkal és segítő tanárokkal támogatják a tanári munkát minden iskolában. (Bunch - Valeo, 2000 In: Pető 2003, p. 11) 
Angliában a Warnock-jelentés gyorsította fel a folyamatot az 1970-es évek végén. A gyógypedagógiai iskolák és eredményességük nagyszabású felülvizsgálatát rendelte el a kormány a hetvenes években, s erre külön bizottságot, az ún. Warnockbizottságot hozták létre, mely többévi munka után 1978-ban tett le egy átfogó dokumentumot, a Warnock-jelentést. Ez rendkívül elégedetlen volt a gyógypedagógiai intézmények hatékonyságával, s többek között hangsúlyozta, hogy az eredményes gyógypedagógiai ellátás egyetlen kritériuma az egyes gyermekek szükségleteire adott lépések eredményessége lehet. Továbbá kiemelte, hogy valamennyi speciális nevelési szükségletû gyermeket integrálni kell az oktatás és a közösségi élet területén. Terminológiai változtatásokat is bevezettek, így a 'tanulási nehézség' (learning difficulty), az 'egyéni fejlesztési terv' (individual education plan), az 'integráció' (integration) fogalmát. (Petô-Endre 2008, p.114). A jelentés közvetlen eredménye volt az 1981-ben megjelent s azóta többször módosított angol közoktatási törvény, mely zöld utat adott az integrált oktatásnak alap-, közép és felsőfokon egyaránt, de nem szüntette meg a speciális intézményeket sem, melyek azóta számban és az ellátottak létszáma terén ugyan csökkentek, de léteznek. (Csányi-Perlusz 2001, p.316)

Német nyelvterületen, ahol a második világháborút követően jól múködô speciális gyógypedagógiai intézményrendszert alakítottak ki, az integrációs törekvések némi késéssel, az 1980-as évek közepétól jelentkeztek erôteljesebben. (Borsfai 2007, p. 29) Az integrált oktatásra vonatkozó elképzelések gyakorlati megvalósítása a 1970-es évektől kezdôdően a fejlett nyugati országokban egy hosszantartó és sokrétû reform-folyamat keretében történt, amelynek során az addig szinte kizárólagos pozícióban levô speciális iskolák mellett számos új szerveződési forma jött létre és terjedt el: a mainstream oktatás iskoláiban speciális osztályokat alakítottak ki, s ezzel egyidejúleg különféle új támogató intézményi struktúrákat, pedagógiai forrásközpontokat hoztak létre. E struktúrák keretében kulcsszerepet töltöttek be az integrált oktatást támogatni hivatott, e területen speciális képzettséggel rendelkezó pedagógus szakemberek, az utazótanárok.

Az integráció elvére alapozott strukturális és koncepcionális átalakulások fontos előrelépést jelentettek az oktatási szolgáltatásokhoz való egyenlő hozzáférés emberjogi megalapozottaságú érvényesítése terén, enyhítették a fogyatékos tanulók térbeli és társadalmi szegregációját. Ugyanakkor hiányosságként könyvelhetô el, hogy a reform megvalósítása során a hangsúly fooleg a fogyatékkal élő tanuló helyzetére, a „normál” iskolai környezetbe való beillesztésére esett, és kevésbé a megfelelő - iskolai és iskolán kívüli - hatékony támogató környezet kialakítására. A térbeli szegregáció felszámolását önmagában is eredménynek tekintô és a hirtelen, kellő elókészítés és megfelelő kisegítő szolgáltatások nélkül betagolt tanulók számának mindenáron történô növelésére koncentráló oktatáspolitikai törekvések sok esetben ellentmondásos eredményeket produkáltak, éppenséggel növelhették is az ily módon „integrált”, mainstream iskolai társaikhoz kellő segítség hiányában felzárkózni képtelen tanulók kiszorítottság-érzését. A"normalizációt” , a „felzárkóztatást” gyakran a beolvasztás szinonímájaként értelmező nevelési gyakorlatok az ,integrálni” kívánt tanulótól kimondva-kimondatlanul - egyoldalú alkalmazkodást vártak el, ami sajátos iden- 
titásuk, a másságukban hordozott tipikus kulturális-közösségi értékek (például a hallássérültek esetében a siketkultúra és nyelv közösségépítő szerepének, értékének) feladását, a kulturális sajátosság társadalmi érvényesítéséról való lemondást igényelte.

Éppen e hiányosságok következtében érlelődött fokozatosan - a múlt század nyolcvanas éveinek második felétôl kezdve - egy újfajta látásmód, egy új típusú politikai és elméleti perspektíva, amely az integrációt már sokkal inkább a pozitív kibontakozást szolgáló eszköznek, mintsem önmagában értékes célnak tekinti. Az új perspektíva, amely a teljes befogadást, pontosabban a kölcsönös be- és elfogadást, az „egyenrangú és egyformán értékes sokfélék” egymást gazdagítását túzi ki célul, a társadalmi inklúzió, ezen belül pedig a nevelési inklúzió gondolata és fogalma köré épül fel. Az inklúzió fogalma (amelynek mindmáig hiába keresték a teljes mértékben kielégítő magyar megfelelőjét) a kirekesztéstől való mentességet kifejezó pozitív fogalom (Ferge 2002).

A fogyatékossággal élókre vonatkozó európai politikában 1996-ban történt jelentôs áttörés. (European Commission 1996) Ekkor fogalmazták meg elôször centrális célkitûzésként az egyenlô esélyek biztosításának alapelvét. Ily módon a társadalmi inklúzió (social inclusion) fogalma, amely eredetileg a szociológiában, majd szociálpolitikai koncepciókban jelent meg, politikai kulcsfogalommá vált, s ezzel párhuzamosan kapott teljes közpolitikai ,polgárjogot” a pedagógiai inklúzió gondolatköre is. (Schiffer 2008, p. 45) E tekintetben fontos elôrelépés volt az Európai Unióról szóló szerzôdés módosítása, amely a szociálpolitikát és foglalkoztatáspolitikát európai közösségi politika szintjére emelte. Az Európa Tanács 1998. évi (1355) ajánlása a társadalmi életből való kizárás multidimenzionális- és folyamat-jellegét emeli ki, amely „magába foglalja a társadalmi, gazdasági, politikai és kulturális életben való részvétel nem megfelelő szintjét, egyenlôtlenségeit, vagy teljes hiányát. (Council of Europe 1998)

További haladást jelentett, amikor 2000-ben az Európai Bizottság elfogadta az „Akadálymentes Európáról” szóló jelentést (European Commission 2000), ugyanebben az évben pedig az Európai Unió Tanácsa kiadott egy, a tagállamok számára kötelezô direktívát a fogyatékkal élők esélyegyenlőségének biztosítására. Az erre vonatkozó - 2000-ben elfogadott - cselekvési terv 2010-ig fogalmazta meg ezen a területen a feladatokat (Council of the European Union 2003).

E vonatkozásban a legfrisebb dokumentum az Európai Bizottság 2010 november 17-én kihirdetett, az Európai Fogyatékosügyi Stratégiáról (2010-2220) szóló határozata (European Commission 2010), amely nyolc fô fellépési területet jelölt ki: akadálymentesítés, részvétel, egyenlôség, foglalkoztatás, oktatás és képzés, szociális védelem, egészség és külső fellépés.Ezeket a területeket az alapján választották ki, hogy milyen mértékben képesek hozzájárulni a stratégia és az ENSZ-egyezmény átfogó célkitúzéseihez, továbbá az uniós intézmények és az Európa Tanács ehhez kapcsolódó szakpolitikai dokumentumai, az EU-nak a fogyatékos személyekkel kapcsolatos cselekvési tervének (2003-2010) eredményei, valamint a tagállamokkal, az érdekelt felekkel és a nagyközönséggel folytatott konzultáció alapján. 
Az egyenlő esélyek biztosításának követelménye az európai uniós dokumentumokban és az azokat megalapozó nyugati elméleti szakirodalomban tehát egyaránt szervesen kapcsolódik a társadalmi exklúzió leküzdésének, a lehetô legmagasabb szintú inklúzió elérésének alapelvéhez. Az egyenlő esélyek biztosításához az inklúzió megvalósulásán keresztül vezet az út. „Az inklúzió és az aktív részvétel elengedhetetlen az emberi méltóság megórzéséhez és az emberi jogok gyakorlásához. Az oktatás területén belül mindez olyan stratégiák kidolgozását jelenti, amelynek célja a lehetőségek teljes körú egyenlősége... Az inkluzív iskolák lényege, hogy a sajátos nevelési igényú tanulók megkapjanak minden támogatást, ami szükséges a sikeres oktatásukhoz." (Salamancai Nyilatkozat 1994)

Az új társadalmi-politikai gyakorlatot megalapozó szemléletváltás szükségszerúen napirendre tûzte a kérdéskörre vonatkozó társadalomkutatás elméleti alapvetéseinek, fogalomrendszerének, koncepcionális és módszertani apparátusának megfelelő átalakulását is. A társadalmi exklúzió sokdimenziós- és egyben folyamatjellegéból fakad a kirekesztettség dimenzióinak, társadalmi színtereinek és megnyilvánulási formáinak sokfélesége, egymást kölcsönesen determináló-megerôsítő, folyamatosan újratermelő természete. A fogyatékosággal élő személyek inklúzióját elősegítő cselekvési stratégiák megalapozásánál ugyanakkor azt is fontos szem előtt tartanunk, hogy a sérültek nem képeznek sem önálló, sem homogén szociológiai csoportot. A támogató szolgáltatásoknak éppen ezért egyénre és helyzetre szabottnak kell lenniük, megtervezésüknél az uniformizált megoldások helyett az alternatívák bơvítésére kell törekednünk. (Fónai-Pásztor-Zolnai, 2007, p.115-119).

Ebben az értelmezési keretben az oktatási exklúzió - amely az oktatási szolgáltatáshoz való teljes körú hozzáférésból való kizáródást, illetve e szolgáltatásokhoz való hozzáférés terén mutatkozó egyenlôtlenséget, valamint a magas szintű tanulmányi teljesítmény elérésének társadalmi okok által determinált alacsonyabb esélyét jelenti - okát és egyszersmind okozatát is képezi-képezheti a munkaerőpiaci, társadalmi mobilitási esélyegyenlootlenségnek, s ezen keresztül a társadalmi kirekesztettség többi megnyilvánulásainak. Egy nemrégen végzett, az oktatási intézmények exklúziót erôsítô szerepét tanulmányozó kutatás eredményei e vonatkozásban arra utalnak, hogy az oktatási intézmények hajlamosak fenntartani és újratermelni azokat az akadályokat amelyek tartósítják a fogyatékos személyek exklúzióját és gettósodását. A fogyatékkal élố tanulók helyzetét nem annyira e fogyatékosság sajátos jellegzetességei befolyásolják, hanem inkább a felsôoktatás és felsôoktatók sokféleségre, kölönbözôségre adott válaszainak milyensége. (Madriaga-Goodley 2010)

Arra is fel kell figyelnünk ugyanakkor, hogy az oktatási exklúzió olyan kulcspozíciót tölt be a társadalmi exklúzió újratermelődésében, ahol megfelelő társadalmi beavatkozással esély nyílik az egymást erôsítő negatív folyamatok megszakítására. A 2000-es magyar közoktatásról szóló jelentés (Radó 2001) külön fejezetben foglalkozik azzal, hogy a társadalmi hátrányok nem szükségszerúen alakulnak iskolai hátrányokká: a pedagógiai tényezốk meghatározók lehetnek az egyes gyerekek iskolai sikereiben. Olyan oktatási szolgáltatások elterjedése szükséges, amelyek egyszerre biztosítják: 
- az esélyegyenlőséget (mely egyenlő hozzáférést eredményező oktatásszervezési módot jelent)

- és az egyenlő esélyeket (mely a különbségek kompenzációját eredményező befogadó rendszeren keresztül valósul meg).

Az inklúzió kifejezést ilyen értelemben - a esélyegyenlôségi elvnek alárendelt és a lehetô leghatékonyabb társadalmi beilleszkedést elősegítő nevelési koncepcióként először egy kanadai kerekesszékes fogyatékosságügyi aktivista: Marsha Snyderman Forest és barátai kezdték használni, akik 1989-ben az Action for Inclusion címú könyvükben így fogalmazták meg az inklúzív nevelés célját:

„A jó iskolákat még jobbá teszi, ha az iskola közelében élô összes gyermeket befogadják. A jó tanárokat még hatékonyabbá teszi, ha az osztály valamennyi tagját bevonják az aktív tanulásba, mindenkinek egyéni feladatokat adnak, és a tanuláshoz szükség esetén többlettámogatást is nyújtanak. A tanulókat jobban fejleszti, ha különbözố képességú személyek is jelen vannak az életükben, és ha minden tanuló biztonságban érzi magát, mert egyéni segítséget kap, amikor szüksége van rá. A családokat megerôsíti, ha a tanárok és a tanulók összefognak azért, hogy létrehozzanak egy olyan osztályt, amely mindenkiért tesz." (O'Brien - Forest 1989 In Schiffer 2008, p. 47)

Az inklúziós folyamat ebben az értelmezésben nem egyszerúen csak - és nem feltétlenül - arra vonatkozik, hogy a nevelési hátránnyal küzdő fiatalokat a speciális iskolából mainstream iskolákba vagy osztályokba helyezik át, hanem mindenekelőtt egy új típusú kapcsolatrendszer és kommunikációs mechanizmus kialakulását feltételezi szülók, nevelók és a gyerekek között. Sebba (1996, p. 2) szerint az inklúzió és az integráció között a következô alapvető különbség áll fenn:"...az integrációval be kívánják olvasztani az iskola meglévô struktúráiba az egyénekel vagy a gyermekek kis csoportját, míg az inklúziónál újra átgondolják a tanterv megvalósításának szerezeti kereteit" és azokat a feltételeket, melyekkel valamennyi tanuló haladását biztosítani tudják. Ezzel hozható összefüggésbe Ainscow (1995) megállapítása, aki szerint az inklúzió révén megvalósul az iskolarendszer általános fejlesztése, az iskolákat úgy lehet megszervezni, hogy valamennyi gyermek, ezen belül a fogyatékossággal élő gyerekek nevelési szükségleteit is, maximálisan kielégítsék.

Hall (1992) értelmezése szerint a fogalom azt is jelenti, hogy az együttes fejlesztésen túl, a tanulókat valóban szociálisan is befogadja az intézmény gyermekés felnôttközössége, tehát hatékonyan megvalósul a diszkrimináció elleni küzdelem. Az iskola mindenki számára sokkal hatékonyabbá válik, hiszen ahogyan ezt Hegarty (1993) hangsúlyozza, az iskola befogadó jellegét a tanítási programok, a pedagógiai felkészültség, a szervezés és a tárgyi, személyi feltételek megléte adja. (Csányi Perlusz 2001, p. 319) Az inkluzív iskola fogalma tehát nem elsôsorban egy bizonyos szervezési forma másikkal szembeni preferálásáról szól, hanem mindenekelőtt a nevelési gyakorlat hatékony társadalmi integrációt elókészítő orientáltságát és ezirányú magas szintú teljesítôképességét jelenti. Vagyis olyan iskolákat nevezhetünk inkluzív iskolának, ahol a sajátos nevelési igényű tanuló hatékony segítséget 
kap arra, hogy maximalizálja társadalmi beilleszkedési és mobilitási esélyeit, hogy eljusson a társadalmi integráció általa elérhető legmagasabb szintjére.

Az inklúzió e stratégiáját nevezI Tetler „hozzunk létre rugalmas iskolákat" megközelítésnek. Az inkluzív iskolák célja - eltérôen az ,integrált iskola” modelljétôl nem egyszerûen az, hogy lehetôvé tenni a fogyatékkal élő tanulók számára, hogy integrálódjanak egy már kialakult érték- és normarendszerrel rendelkezó csoportba, amelynek értékeihez és normáihoz alkalmazkodniuk kell. Ehelyett, illetve ezen túlmenő́en - inkább abban látják szerepüket, hogy létrehozzanak egy olyan iskolai kultúrát, amely minden tanulót befogad. „A kiindulópont ebben az esetben, hogy minden tanuló a helyi tanulóközösséghez tartozik, és éppen ezért az erőfeszítéseknek arra kell irányulniuk, hogy olyan kultúrát teremtsünk. amely a gyermeket nem zárja ki a közösségbool. A felelôsség mindannyiunké, és megkívánja az iskola szerkezetének átgondolását, beleértve a tantervet, a munkamódszereket, a szervezeti kereteket, továbbképzéseket stb.. (Tetler 2006, p. 36)

A társadalmi modell és az inklúzió gondolatának megvalósításától elválaszthatatlan az a tény, hogy a fogyatékosság, zavar, akadályozottság fogalmát felváltja a sajátos nevelési igény (special educational need) megjelölés. Ennek elsô megfogalmazása a már említett Warnock-jelentésben található meg. A megjelölés pozitív hozzáállást tükröz, mely nem az adott személyben rejlő hiányosságokat, a képességek elmaradottságát hangsúlyozza, hanem a pedagógiai teendóket. (Csányi - Perlusz 2001, p. 317) A hátrányos helyzetú gyermekek iskolai inklúzióját folyamatként tekintve- a szakirodalomban fellelhetô információk és saját gyakorlati tapasztalatunk szintéziseként - a következô ,lépcsőfokokat” különíthetjük el:

\section{1. korai felismerés}

2. elfogadás

3. korai fejlesztés

4. inkluzív óvodai intézményes keret

5. inkluzív iskola

6. inkluzív szakképzés, felsőfokú képzés

7. a munkahelyi és családi/közösségi inklúzió előkészítése

Az új megközelítésmód egyformán értékesnek ismeri el minden, a folyamatban résztvevô társadalmi kulcsszereplő hozzájárulását, a nevelési gyakorlatot pedig mindannyiuk összehangolt erőfeszítései közös produktúmának tekinti. Ezáltal egy olyan nevelési közösség jön létre, amely a a pedagógiai eszköztáron túlmenôen a problémamegoldás társadalmi lehetôségeit is igyekszik hasznosítani, esélyt biztosítva az érintettek nagyobb mértékú bekapcsolódásához, sajátos tapasztalataik hasznosításához, a nevelési célkitűzések sikerességét gátló szubjektív feltételrendszerek megváltoztatása érdekében. (Laluvein 2010)

A nemzetközi szakirodalom az inkluzív oktatási gyakorlat fontos jellemzőjeként jelöli meg a nevelés értelmi, érzelmi és szociális dimenzióinak egymással összefonódó, egymást pozitív hatását kölcsönösen erôsítő felhasználását. E vonatkozásban 
különleges jelentőséggel bír a szociális és érzelmi tanulás (az angol nyelvú szakmunkákban Social and Emotional Learning-SEL) kölcsönviszonya az inkluzív neveléssel. A SEL a személyiségfejlődésre, a személyközi kapcsolatépítési képességek és a problémamegoldó képességek és kompetenciák fejlesztésére irányuló nevelési és szocializációs folyamatként határozható meg. Ez a folyamat formális és informális környezetben valósul meg, hatékonyságát számos egyéni, helyzetfüggô és kulturális tényező kölcsönhatása befolyásolja. A személyiségcentrikus látásmódon túlmenôen, a SEL nagy hangsúlyt helyez a támogató oktatási környezet, kialakítására, ezért fơként a nevelési tér szociális és emocionális összetevőire koncentrál (Reicher, 2010).

Az inkluzív oktatás problematikáján belül egy másik - az elóbbiekhez szorosan kapcsolódó - fontos kérdéskör a kulturális identitás megörzésének, kifejezésének, újratermelésének lehetőségére vonatkozik. A hallássérültek oktatásának esetében például e követelmény tiszteletben tartása felveti a siketkultúra - és hordozója, a jelnyelv -ápolásának, a tanulók személyiségfejlesztésére irányuló nevelési stratégiákba történő beépítésének, a tanulók és nevelők közötti, valamint a halló és nem halló tanulók közötti interakciós folyamatokban megvalósítandó pedagógiai értékesítésének szükségszerúségét és mikéntjét. Az inkluzív nevelést az az alapvetô szemlélet jellemzi, mely a tanulók egyéni különbségeit (akár társadalmi, akár kulturális, akár biológiai) komplexitásában tekintve, maximálisan figyelembe véve, azokból kiindulva, azokra építve alakít ki befogadó környezetet, ahol a nevelési térben résztvevô valamennyi személy (tanárok, diákok, szülók) a kölcsönös együttmúködés szellemében megismerik egymást, értékként fogadják el és építenek az egyéni különbségekre (Torgyik 2004). Az inklúzió célja nem a láthatatlanná válás, nem a beolvasztás, nem a hagyományok, kultúra, vallás elfelejtése, hanem éppen a láthatónak maradás, a megkülönböztető tulajdonságok megmaradásának lehetôsége (Szira 2005).

Megkülönböztetett súllyal vetődik fel ez a kérdés a súlyosan fogyatékos gyerekek és fiatalok befogadása tekintetében. Az Amerikai Egyesült Államok tanulóinak például 1\%-át sorolják a súlyos fogyatékkal élók kategóriájába, ide értve a szellemileg visszamaradt tanulókat. Velük kapcsolatban alakult ki történelmileg az az álláspont, hogy alkalmatlanok lennének nemcsak az inkluzív nevelési közösségekbe való bekapcsolódásra, az ehhez szükséges interakciós kézségek elsajátítására, de az iskolai általános tananyag befogadására is. A nemzetközi szakirodalomban azonban újabban komoly érveket fogalmaztak meg amellett, hogy megfeleló pedagógiai módszerek, gyakorlat alkalmazásával e gyerekek esetében is lehetséges az inklúzió szimbolikus, a hovatartozást kifejezô én-tudat pedagógiai úton történô megkonstruálásán alapuló inklúziós modell érvényesítése. (Bentley 2008).

Végül, de nem utolsó sorban, a társadalmi befogadás és felzárkózás feltételeinek kialakításában az élethosszig tartó tanulás fontos szerepet hivatott betölteni. A felnőttkori tanulás révén ugyanis olyan korrekciós, kompenzációs mechanizmusok építhetôk be az oktatási rendszerbe, amelyek hozzájárulhatnak az elmúlt évtizedek egyenlőtlenséget, kirekesztettséget újratermelô szelekciós mechanizmusainak és oktatási gyakorlatainak megszüntetéséhez. A felnôttoktatás számos lehetôséggel 
bír a fogyatékosságról és a fogyatékos személyekról szóló közhiedelmek, felsőbbilletve alsóbbrendúségi perecepciók, előítéletek lebontásában is. E folyamat során kulcskérdésként jelentkezik olyan nevelési alkalmak, találkozási helyzetek létrehozása, amelyek során a fogyatékos személyek tanulóként és oktatóként-nevelóként egyaránt megismerhetik egymást. (McLean 2008)

\section{Kérdôjelek és lehetséges válaszok}

Az inkluzív nevelés célkitűzései az egész világon kihívást jelentenek az oktatási rendszerek számára, a fejlődő és fejlett országokban egyaránt. A kétségtelenül megvalósuló pozitív folyamatok ellenére a szemléletmódok és társadalmi gyakorlatok tényleges megváltozása tekintetében még korántsem beszélhetünk teljes átalakulásról. Íme néhány, az új koncepciók életbe ültetését lehetôvé tevô tudástranszfert akadályozó fontosabb tényezók közül:

- A status quo-t erôsítô hagyományos szociológiai szemléletmód erôs pozíciói.

- Az orvosi modell, amely a beavatkozást elsósorban nem társadalmi-politikai, hanem egészségügyi-rehabilitációs feladatnak tartja, továbbra is jelentôs befolyással bír szakmai körökben.

- A fogyatékos személyek marginális társadalmi helyzete, gyenge érdekérvényesítô képessége miatt a fogyatékosügy marginális, háttérbe szoruló társadalmi és kutatási problémaként jelenítődik meg a köztudatban.

Ainscow és Sandill (2010) a nemzetközi szakirodalomban fellelhető kutatási adatok és eredmények alapján arra a következtetésre jutottak, hogy a vezetői gyakorlat kulcsszerepet tölhet be a szemléletváltási folyamatban, azáltal, hogy a az oktatási rendszereket az inklúziós értékek felé irányítja és ezáltal elősegíti a fenntartható változást. Ennek elôsegítése érdekében taglalják a pozitív irányú kibontakozás szervezeti előfeltételeit, különösképpen az inkluzív kultúrát erősítő vezetési módszerek szerepének tekintetében.

E vonatkozásban az EU új tagjai - a rendszerváltást 1989 után megvalósító közép-keleti országok - érthetóen lemaradásban vannak a kontinens nyugati felével szemben. A kommunista rendszerek a fogyatékosságot elsôsorban adminisztratív kérdésként kezelték a nyilvántartásba vétel és a hiányosságot kompenzáló - de egyben a teljes körú társadalmi érvényesülésnek is határokat szabó - intézménybe juttatásuk érdekében A szociológiai kutatás számára a fogyatékosügy - országonként eltérô mértékben és módon - ideológiai tabu-témának számított (Romániában például csaknem teljesen, Magyarországon bizonyos orvosi modell-centrikus vagy jobb esetben életminôségkutatásnak alárendelt megközelítésekre volt lehetôség).

1989 után e tekintetben is új perspektívák nyíltak, a posztkommunista átmeneti időszak sajátosságai azonban továbbra sem kedveztek annak, hogy a marginális 
helyzetú társadalmi csoportok a politikai, pedagógiai és kutatási érdeklődés fơ áramába kerüljenek. A különböző hátrányos helyzetú csoportok érdekeit szem előtt tartó intézményesített tevékenységek nagyon nehéz körülmények között indultak meg. A kommunista hatalom korszakában a fogyatékosságokkal foglalkozó irodák és intézmények az államhoz tartoztak, munkatársaik állami hivatalnokok voltak. Sokuknak nem volt könnyű szervezetileg és pénzügyileg is új lehetôségeket és felelősséget feltételező életet kezdeni 1989 után. Az autentikus civil szervezetek létrehozása, amelyek szakítani képesek az idejét múlt struktúrákkal és mentalitásokkal, igen nehéz és problematikus folyamatként jelentkezett. A pénzügyi források elégtelensége, a jogi rendszer túlszabályozó jellege, valamint megfelelő számú szakember hiánya, olyanoké, akik képesek lennének egy demokratikus (vagy afelé haladó) környezetben dolgozni, további okait képezik a fejlődés lassúságának. (Flora 2003, p.256).

Mindezek ellenére, a szolgáltatásokat érintô jelentős mértékú fejlődés mellett - amelyben jelentôs szerepe volt a nyugati országokból érkezô anyagi és szakmai támogatásnak - elvi-koncepcionális szinten is lényeges változások következtek be, illetve kezdődtek el. Ezek közé sorolható:

a. a terminológia részbeni megújulása, új kifejezések elterjedése és mind gyakoribb használata (pl. „fogyatékkal élő személyek”, „,sajátos szükségletű személyek”, „sajátos nevelési igények", inklúzió, esélyegyenlôség)

b. új, az európai uniós politikák életbeléptetését célzó tematikák megjelenése (pl. akadálymentesítés, integrált oktatás, inkluzív nevelés, emberi jogok, közösségi jogok)

c. a fogyatékkal élő személyek jogait szabályozó, a fogalomhasználatban és szemléletmódban bekövetkezett változást tükrözô új törvényes keret kialakítása

Ami a fejlődő országok helyzetét illeti, Miles és Singal (2010) felhívják a figyelmet arra a tényre, hogy a sajátos nevelési igényekkel rendelkező gyerekek sajnálatos módon jórészt kívül maradnak a Nevelést Mindenkinek (Education For All- EFA) program megvalósítóinak látókörén, különösen a Harmadik Világ országaiban, ahol a mainstream oktatásba be nem kerülő fogyatékosággal élő tanulók részaránya becslések szerint még mindig 90-98 \% között van. Indiában, például, annak ellenére, hogy a kormány jelentôs erőfeszítéseket tett azért, hogy a fogyatékkal élő gyerekek megkapják a nemzetközi ajánlásoknak megfelelő szintű segítséget, 2003-as adatok szerint 90\%-uk továbbra is kívül marad az ellátórendszeren. (Kalyanpur, 2008) A kevésbbé fejlett országokban sokan úgy vélekednek: a fogyatékossággal élő tanulók nevelésére nem megfelelőek az egyébként is túlzsúfolt és alulfinanszírozott oktatási intézmények.

A legjobb helyzetben nyilván - e tekintetben is - a fejlett nyugati országok állnak, ahol az inkluzív nevelés ma már a globális közpolitikai napirend részévé vált, és ennek megfeleloen a különbözo országok kormányai és kormányzati szervei arra törekednek, hogy inklúziót elosegíto politikákat dolgozzanak ki és léptessenek életbe. E „kiváltságos” országcsoport esetében is mindinkább nyilvánvalóbbá válik azonban, hogy az alkalmazott ,jó gyakorlatok” - foként a körülmények sokfélesége, 
valamint részben ebbol következo heterogenitásuk és helyzetfüggoségük miatt is - sok esetben nem alkalmasak arra, hogy egész közpolitikai koncepciókat építsenek rájuk. E célból történo részleges hasznosításuk szelektív kritikai viszonyulást, sokrétủ összehasonlító elemzési perspektíva alkalmazását igényli. (Wright 2010)

A nemzetközi szakirodalmat tanulmányozva nem kerülhetik el azonban figyelmünket olyan értelmú jelzések, miszerint a kezdeti lelkesedést követóen a nyugati támogató szakemberek de a pedagógusok körében is egyre inkább terjedni látszik a változások kapcsán egy bizonyos egy olyan jelenségkomplexum amelyet Bourke (2010) a következő fogalmakkal jellemez: „összezavarodottság, frusztráció, vétkességérzet és kimerültség." A szerzô e helyzet kialakulásának okát abban látja, hogy a változások meghonosítását nem elôzte meg az új rendszer eszmei megalapozásául szolgáló - a fogyatékosságról, különbözőségrôl és inkluzióról kialakított - előfeltevések kritikai elemzése, a rendszert életbeléptetô és múködtetô szakemberek ehhez sem elegendô idôt, sem anyagi támogatást nem kaptak. Véleménye szerint a kiútkeresésben célravezetô lenne, ha a reformokat annak fényében értékelnék: milyen mértékben visznek azok közelebb a kiindulóponként szolgáló inklúziós célokhoz, milyen tényleges hatást fejtenek ki a tanulói népességre, valamint a tanulókat támogató nevelési szakemberekre.

Egy további kérdőjel az inklúzióra vonatkozó felfogások terén a sajátos nevelési igénnyel kapcsolatos értelmezési lehetőségekre vonatkozik. Bár a sajátos szükségletek fogalma központi szerepet tölt be a speciális nevelésre vonatkozó szakdiszciplínákban, a fogalom jelentéstartalma, elméleti-filozófiai alapjai még nem kellóképpen tisztázódtak. E helyzet - amint erre több szerzố is rámutat - negatívan befolyásolja a hatékony inklúziós oktatási politikák elméleti és gyakorlati megalapozásának esélyeit is.

Vehmas (2010) e kérdéskört taglalva igyekszik feltárni, hogy milyen szükségletekról van szó és milyen alapon határozhatók meg ezek „sajátos” vagy „,különleges” szükségletként. Arra a kérdésre is kitér, hogy vajon a szükségletek két külön kategóriába sorolása - a „közönséges” és a „speciális” sszükségletek megkülönböztetése - önmagában nem jelent-e diszkrimitatív jellegú különbségtetelt. A szerzô válasza e kérdésre egyértelmú „nem”. A „sajátos szükségletek” értelmezésében kimutatható individualisztikus megközelítésmód lényeges hiányosságokat hordoz ugyan magában, de önmagában nem vezet a sajátos szükségletekkel rendelkezô tanulók diszkriminálásához. Ellenkezóleg, az egyéni képességek és sajátosságok bekerülése a nevelôi érdeklődés középpontjába, valamint az egyén társadalmi környezete minôségének javítására irányuló pedagógiai törekvések lényegi elófeltételeit képezik olyan befogadó társadalmak és iskolák kialakításának, ahol az alapvetô jogelvek, a méltányosság elvei érvényesülhetnek. A speciális iskolák inkluzív pedagógiai szolgáltató központokká történô átalakulása olyan folyamatot jelöl, amelynek során kulcsfontosságú, hogy mikor sikerül kialakítani és életbe léptetni az individualizált, egyéni nevelési szükségletekre koncentráló, de a közösségi integrációt is elôsegítô munkaterveket. 
A különbözőség konceptualizálása kulcskérdés az inkluzív pedagógiában és lényegbevágó szerepe van az inkluziót elősegítő közpolitikák megvalósításában is, ebből pedig értelemszerúen következik, a sajátos szükségletekkel rendelkező gyerekeket fogadó pedagógusok speciális képzésének rendkívüli jelentősége. (Harwood 2010) Tanulságos e vonatkozásban egy ausztráliai tapasztalatokat összegző tanulmány, amelynek szerzôi új típusú továbbképzési programot mutatnak be. E képzés célja hozzásegíteni az oktatókat az inkluzív oktatási környezetbe beillesztett hallássérült gyerekekkel végzett hatékony nevelőmunkához. A kutatás során a továbbképzési program struktúráját és tartalmi összetevóit, pedagógiai és filozófiai megalapozását vizsgálták. A program megvalósítása során a speciális oktatók szorosan együttmúködtek általános kompetenciájú pedagógus-társaikkal. (Furlonger et al 2010)

Egy másik, hasonló témakört taglaló, tanulmány szerzői rávilágítanak arra, hogy a mainstream iskolákban múködő gyógypedagógusok, segítő szakemberek szerepértékelése kapcsán az érintettek körében is bizonytalanság mutatkozik. A vonatkozó kutatás Hong-Kong-i magániskolák inklúziót elősegítő oktatási asszisztensei számára szervezett képzés hatékonyságát mérte fel és értékelte ki, amelynek célja az inkuzív nevelési gyakorlatok iskolai környezetben történô alkalmazásának támogatása, erôsítése volt. Az oktatói asszisztensek képzéssel kapcsolatos várakozásait és percepcióit kérdőíves felmérés és interjúk segítségével rögzítették. A kutatás eredményei azt mutatják, hogy a képzés sikeresen megfelelt az asszisztensek elvárásainak, erősítette önbizalmukat és önbecsülésüket, azonban kérdőjeleket fogalmaztak meg azzal kapcsolatban, hogy vajon a tanultak milyen mértékben lesznek ténylegesen alkalmazhatók saját oktatási gyakorlatukban. A kutatás ugyanakkor azt is feltárta, hogy az oktatási asszisztensek nem látják világosan saját szerepüket, azt hogy munkájuk miként lenne a lehetô legjobban hasznosítható az iskolákban, s ez a hiányosság korlátozza óket szakmai fejlődésükben is. (Rose-Forlin 2010). Joggal feltételezhetjük, hogy a szociálpedagógiai szempontrendszerek hangsúlyozottabb alkalmazása az oktatási asszisztensek feladatköreinek körvonalazásában és következetes érvényesítésük a képzés során hozzájárulhatna e bizonytalanságérzés enyhüléséhez.

Számos kutatási adat utal arra, hogy az integrációs folyamat számokban mérhetô, sok vonatkozásban formális elôrehaladása ellenére a mainstream iskolákban tevékenykedô pedagógusok viszonyulásmódja sok vonatkozásban alig változott. „Az a nézet, amely a sérülést a személy képességeinek a hiányaként szemléli, jelentôs mértékben fennmaradt. A legtöbb pedagógus, egyáltalán nem meglepően, meg van gyốzôdve arról, hogy a hagyományos osztályok nem alkalmasak a sérült tanulók ellátására, hogy az iskolai elômenetelük nem lehet olyan sikeres, mint lenne egy szegregált iskolában/osztályban, és hogy a normál osztályok diákjainak tanulását hátráltatja a sérült tanuló jelenléte." (Pető 2003, p. 7.)

A fogadó pedagógus nehéz helyzetben van, tanulmányai során jószerint nem is hallott a fogyatékosságról, s az integrációról, inklúzióról sem, vagy ha igen, ez megmaradt elméleti síkon. Nagy jelentôsége lenne tehát annak, hogy a pedagógiai 
szakos hallgatók már tanulmányaik során lehetőséget kapjanak a fogyatékosság jelentéstartalmainak mélyebb megértésére, a fogyatékosság szociális és kulturális modelljeiról szóló együttgondolkodásra. Lényeges, hogy hallgatóként alkalmuk legyen közösen reflektálni saját identitásukra és a fogyatékos emberek identitására egyaránt. Ezáltal olyan, személyes tapasztalatból származó erőforrásokat mozgósíthatnának, amelyek hozzásegíthetik óket a fogyatékosságból eredô másság konstruktív, pozitív töltetû percepciójának megalapozásához. (Baglieri, 2008)

\section{Következtetések}

A neveléstudományok - az esélyegyenlôségi elv szellemében - közös célt tûztek ki az inklúzió tekintetében, de még nem született konszenzus arról, melyik a legjobb út a cél elérésére. Ez a tény nem utolsó sorban az érintett csoportok heterogenitásához, az egyéni helyzetek sokféleségéhez vezethető vissza. A megközelítésmódok, tényleges viszonyulások jelentôs részében - többé-kevésbé nyílt vagy rejtett módon - még mindig a fogyatékosság orvosi értelmezése van túlsúlyban.

A legfontosabb teendő a jelenlegi szakaszban véleményünk szerint annak tudatosítása lenne - a politikai-jogi és szélesebb társadalmi köztudatban egyaránt - hogy a különbözô jogok érvényesítése nem csak a meglévố alkotmányi és jogi normatíváktól függ, hanem fóként attól, milyen eszközök és lehetóségek állnak rendelkezésre a valóságban az illetô jogok gyakorlatba ültetéséhez. (Barnes et al., 1999) Az inkluzív oktatáspolitikák és gyakorlatok tényleges alkalmazása tekintetében igen fontos a „hálózati” szemléletmód érvényesülése, amely a nevelési környezet kulcsszereplőit, szolgáltatásait és intézményeit (szülók, pedagógusok, iskolai és iskolán kívüli, pedagógiai és nem-pedagógiai jellegű szolgáltatások, az oktatási, foglalkoztatási és szociális szféra intézményrendszerei, jogi kerete és közpolitikai programjai) a maguk egységében és kölcsönhatásában fogja fel és veszi tekintetbe.

Az inkluzív oktatási szolgáltatások kiépítésének célkitüzése napirendre tưzte az átalakítások szükségességét a sérült tanulókkal kapcsolatba kerülő oktatók, nevelők képzése, továbbképzése, státusa, szakmai kompetenciái, pedagógiai lehetôségei tekintetében is. Olyan kérdések kerültek előtérbe mint például a speciális iskolában általános tantárgyakat tanító tanárok gyógypedagógiai és szociálpedagógiai képzettségének biztosítása, a pedagógusok alkalmassá tétele az individualizált oktatási módszerek és egyéni nevelési útirányok megtervezésére és megvalósítására, az ún. utazótanárok rendszerének intézményesülése. E vonatkozásban is kezdenek felhalmozódni általánosítható, a helyi körülmények figyelembe vételével kreatívan alkalmazható pozitív tapasztalatok.

\section{Irodalomjegyzék}

Ainscow. M. (1995): Special Needs through School Improvement; School Improvement through Special Needs. In: Clark et al (Eds.) Toward Inclusive Schools? 


\section{Fulton - London.}

Ainscow, M and Sandill, A. (2010) Developing inclusive education systems: the role of organisational cultures and leadership. International Journal of Inclusive Education; Jun2010, Vol. 14 Issue 4, pp. 401-416.

Baglieri, S (2008): 'I connected': reflection and biography in teacher learning toward inclusion. International Journal of Inclusive Education; Sep-Nov 2008, Vol. 12 Issue 5/6, pp. 585-604.

Barnes, C.; Mercer, G. and Shakespeare, T. (1999) Exploring Disability. A Sociological Introduction. Cambridge: Polity Press.

Bentley, J. K. C. (2008). Lessons from the 1\%: children with labels of severe disabilities and their peers as architects of inclusive education. International Journal of Inclusive Education; Sep-Nov 2008, Vol. 12 Issue 5/6, pp. 543-561.

Blau, J. (2010) In Pursuit of Equality of Rights, Dignity for All, Deep Democracy, \& Solidarities. http://www.sociologistswithoutborders.org/index.html (Letöltve, 2010 jún.21.)

Bohrnstedt G.W. (1969) Observations on the measurement of change. Sociological Methodology Borgetta EF (ed), Jossey-Bass, San Francisco, 1969.

Borsfai L. (2007) Együttnevelés vagy különnevelés a sajátos nevelési igényú gyermekek és fiatalok körében. Mester és tanítvány 14. szám, 2007 május, pp. 24-32. Bourdieu, P.(1964) Les héritiers, Jean-Claude Passeron, Minuit.

Bourke, P. (2010) Inclusive education reform in Queensland: implications for policy and practice. International Journal of Inclusive Education; Mar2010, Vol. 14 Issue 2, pp. 183-193.

Bunch, G.- Valeo. A. (2000) Educational inclusion of Children with Disabilities. In: International Scan of Issues: Children with Disabilities and Their families. .1 Congress Discussion Document. 6th International congress on the inclusion of children with disabilities in the community, pp. 178-198.

Castells, M. (2004) The Network Society: A Cross-Cultural Perspective. Cheltenham, UK; Northampton, MA, Edward Edgar.

Coleman, J.S (1964)Models of change and response uncertainty, Prentice-Hall, Englewood Cliffs.

Council of Europe (1998) Reccomendation 1355 Fighting social exclusion and streng thening social cohesion in Europe. Reply from the Committee of Ministers adopted at the 652nd meeting of the Ministers' Deputies (15 December 1998)

http://assembly.coe.int/ Mainf.asp?link=

/Documents/WorkingDocs/Doc98/EDOC8290.htm (Letöltve: 2010. jún. 23.)

Council of the European Union (2003) Council Resolution of 5 May 2003 on equal opportunities for pupils and students with disabilities in education and training (2003/C/134/04). http://www.ozida.gov.tr/raporlar/uluslararasi/ab/ ABmuktesebati/ 2003equalopportunitiespupilsandstudents.pdf (Letöltve: 2010. jún. 22.)

Csányi Y. - Perlusz A. (2001) Integrált nevelés - inkluzív iskola In: Báthory Z. - Falus I. (szerk.): Tanulmányok a neveléstudomány köréból 2001. Osiris Kiadó, Budapest. 314-332. p./ 
Davies, M. (ed.) (2008) The Blackwell Companion to Social Work. Oxford: Blackwell.

European Commission (1996) Communication of the European Commission on equality of opportunity for people with disabilities http:ec.europa.euemployment socialsocprotdisablecom406index_en.htm (Letöltve 2009. január 10.)

European Commission (2000) Towards a barrier-free Europe for People with Disabilities. Communication from the Commission adopted on 12 May 2000. COM(2000) 284final.

European Commission (2010) Európai fogyatékosságügyi stratégia 2010-2020: megújított elkötelezettség az akadálymentes Európa megvalósítása iránt. http://eurlex.europa.eu/LexUriServ/LexUriServ.do?uri=COM:2010:0636:FIN:HU:HTML

(Letöltve 2011.12.01.)

Ferge Zs.(2002) Kétsebességû Magyarország http:www.szmm.gov.hudownload.php ?ctag $=$ download\&docID $=118 \ldots 0$ (Letöltve : 2010. jún 22.)

Ferri, B. A. (2008) Changing the script: race and disability in Lynn Manning's Weights. International Journal of Inclusive Education; Sep-Nov 2008, Vol. 12 Issue 5/6, p 497-509.

Flora G. (2003) Improving Media Access for the Population with Disabled Hearing in Romania and Hungary. In. Sükösd Miklós - Bajomi-Lázár Péter (szerk.): Reinventing Media: Media Policy Reform in East-Central Europe. Budapest: CEU Press, pp. 239-258.

Fónai M.-Pásztor E.- Zolnai E (2007) A fogyatékos emberek helyzete, életmódja és életkörülményei Hajdú-Bihar megyében, Esély, 2007/6, pp. 87-119.

Furlonger, Brett E. Sharma, UmeshMoore, Dennis W. Smyth King, Brian (2010) A new approach to training teachers to meet the diverse learning needs of deaf and hard-of-hearing children within inclusive Australian schools. International Journal of Inclusive Education; May2010, Vol. 14 Issue 3, pp. 289-308.

Hall, J. (1992) Segregation by another name? Special Children, 4. sz. pp. 20-23.

Harwood, Valerie (2010) The place of imagination in inclusive pedagogy: thinking with Maxine Greene and Hannah Arendt. International Journal of Inclusive Education; Jun2010, Vol. 14 Issue 4, p.357-369.

Hegarty. S. (1993) Reviewing the Literature on Integration. European Journal of Special Needs Education. 3. sz. pp.p194-200.

Kalyanpur, Maya (2008) Equality, quality and quantity: challenges in inclusive education policy and service provision in India. International Journal of Inclusive Education; May 2008, Vol. 12 Issue 3, pp. 243-262.

Kozma T.-Tomasz G. (2003) Elôszó In: Kozma Tamás - Tomasz Gábor (szerk.) Szociálpedagógia. Osiris Kiadó, Educatio Kiadó, Budapest.

Kullmann Lajos - Kun Helga (2004) El kell-e felejtenünk az orvosi modellt...? A fogyatékosság jelensége az orvostudományban. Zászkaliczkz Péter, Verdes Tamás (szerk.) Tágabb értelemben vett gyógypedagógia. ELTE-BGGYFK, Kölcsey Ferenc Protestáns Szakkol., Budapest, pp. 69-89. 
Laluvein, Jackie (2010) School inclusion and the 'community of practice'. International Journal of Inclusive Education; Feb 2010, Vol. 14 Issue 1, pp. 35-48.

Lányiné Engelmayer Á. (1993) A külföldi itntegrációs modellek tanulságai a hazai alkalmazás számára. In: Csányi Y. (szerk.) Együttneveles - Speciális igényú tanulók az iskolában. IFA OKI. Budapest, pp. 11-23.

Madriaga, Manuel - Goodley, Dan (2010) Moving beyond the minimum: socially just pedagogies and Asperger's syndrome in UK higher education. International Journal of Inclusive Education; Mar 2010, Vol. 14 Issue 2, pp. 115-131.

Matinvesi. S. (1999): Perspectives and Applications of the ICIDH. In Van Stokkom, S. C. - Fougeyrol- Las. P. (eds.): Proceedings International Workshop on the Use and Usefulness of the International Classification of Impairments. Disabilities and Handicap. Strasbourg. Council of Europe Publishing. pp. 55-60.

McLean, Margaret A. (2008) Teaching about disability: an ethical responsibility? International Journal of Inclusive Education; Sep-Nov 2008, Vol. 12 Issue 5/6, pp. 605-619.

Miles, Susie - Singhal, Nidi (2010) The Education for All and inclusive education debate: conflict, contradiction or opportunity? International Journal of Inclusive Education; Feb 2010, Vol. 14 Issue 1, pp. 1-15.

Oliver, Mike (1996) Understanding Disability: From Theory to Practice. Basingstoke: Macmillan.

Pacifici. A.(1999) Statement on the ICIDH and Vocational Assessment. In Van Stokkom, S. C. - Fougeyrol- Las. P. (eds.): Proceedings International Workshop on the Use and Usefulness of the International Classification of Impairments. Disabilities and Handicap. Strasbourg. Council of Europe Publishing. pp.171-176.

Petô Ildikó - Endre Katalin (2008) Az inklúzió és a Warnock Jelentések - 1978 és 2005. Iskolakultúra, 5-6.szám pp. 112-123.

Petô Ildikó (2003) Inklúzió a nevelésben. Iskolakultúra 10.sz. 2003, pp. 3-12.

Radó Péter (2001): Esélyegyenlôség és iskolapolitika. Új Pedagógiai Szemle, 2001/01. http://www.oki.hu/oldal.php?tipus=cikk\&kod=

2000-01-ei-Rado-Eselyegyenloseg (Letöltve: 2009.05.26.)

Reicher, Hannelore (2010) : Building inclusive education on social and emotional learning: challenges and perspectives - a review. International Journal of Inclusive Education; May2010, Vol. 14 Issue 3, pp. 213-246.

Rose, Richard and Forlin, Chris (2010) Impact of training on change in practice for education assistants in a group of international private schools in Hong Kong. International Journal of Inclusive Education; May 2010, Vol. 14 Issue 3, pp. 309323.

Salamancai Nyilatkozat és Cselekvési Tervezet (1994)

http://www.barczi.hu/letoltesek/tudomanyos_testuletek/dokumentumok/

SALAMANCAMagyar.pdf (Letöltve 2010.12.15.)

Schiffer Csilla (2008) Az inklúzió fogalmának értelmezései és azok ellentmondásai In: Bánfalvy Csaba (szerk). Az integrációs cunami: tanulmányok a fogyatékos emberek iskolai és társadalmi integrációjáról. ELTE BGGYFK, ELTE Eötvös Kiadó, 
Budapest, 2008, pp. 45- 63.

Sebba. J. (1996): Developing Inclusive Sehools. (Budapesten elhangzott előadás kézirata).

Szira Judit (2005): Gondolatok az integráció nemzetközi gyakorlatáról. In Mayer József (szerk.): Innovatív környezet, inkluzív társadalom, integratív iskola. Országos Közoktatási Intézet, Budapest. http:www.oki.huoldal.php?tipus=cikk\&kod= 3I-Szira (Letöltve: 2009.01. 20.)

Torgyik Judit (2004): Hatékony iskola: együttmúködó iskola. Új Pedagógiai Szemle, 4/2004, 26-38.

Tetler, Susan: Inkluzív osztályok: a tanítás és tanulás modelljei, dilemmák és kihívások In: Iskolakultúra, 16. 10. 2006. pp. 36-42.

Vehmas, Simo (2010): Special needs: a philosophical analysis. International Journal of Inclusive Education; Feb 2010, Vol. 14 Issue 1, pp. 87-96.

Wright, Kevin (2010) 'Count us in' - achieving inclusion in Scottish schools: an analysis of policy. International Journal of Inclusive Education; Mar 2010, Vol. 14 Issue 2, pp. 153-164. 
Belényi Emese szociológus

Partiumi Keresztény Egyetem, Nagyvárad Bölcsészettudományi Kar, Társadalomtudományi Tanszék 